\title{
A Processed Grain Food Inhibits Hepatic Injury in Endotoxemic Rats*
}

\author{
Yukiko Minamiyama,,${ }^{1, * *}$ Shigekazu Takemura, ${ }^{2}$ Shinya Toyokuni, ${ }^{3}$ \\ Yuko Tanimoto, ${ }^{1}$ Eisuke F. SATO ${ }^{1}$ and Masayasu Inoue ${ }^{1}$ \\ Departments of ${ }^{1}$ Biochemistry and ${ }^{2}$ Surgery, Osaka City University \\ Medical School, Osaka 545-8585, Japan \\ ${ }^{3}$ Pathology and Biology of Diseases, Graduate \\ School of Medicine, Kyoto University, Kyoto 606-8501, Japan
}

(Received February 25, 1998)

\begin{abstract}
Summary Although various antioxidants have been tested as therapeutics for endotoxemic subjects, the results of their efficacy are conflicting. Antioxidant biofactor (AOB) is a unique processed grain food that exhibits strong antioxidant activity (Minamiyama et al, J Nutr Sci Vitaminol, 40: 467-477, 1994). The present study was carried out to test the effect of AOB on hepatic injury in rats induced by lipopolysaccharide (LPS). Intravenous administration of LPS induced liver injury with a concomitant increase in hepatic generation of nitric oxide (NO) and 4-hydroxy-2nonenal (HNE) modified proteins in the control group. The administration of AOB significantly inhibited the LPS-induced hepatic injury and generation of HNE-modified proteins and increased the survival rate of endotoxemic rats without affecting NO generation and plasma levels of tumor necrosis factor- $\alpha$ (TNF- $\alpha$ ) and interferon- $\gamma$ (IFN- $\gamma$ ). AOB scavenged superoxide radicals without affecting NO production by LPS-stimulated macrophage cell line J 774.2 cells. AOB also inhibited lipid peroxidation induced by LPS in the cells. These results suggested that AOB might scavenge superoxide radicals and decrease toxic metabolites including $\mathrm{HNE}$, thereby inhibiting liver injury in endotoxemic rats.
\end{abstract}

Key Words antioxidant, rat, free radical, endotoxin, hepatic injury

\footnotetext{
* This work was supported by the Osaka City University Medical Research Foundation Fund for Medical Research.

** To whom correspondence should be addressed. E-mail: yukiko@msic.med.osakacu.ac.jp

Abbreviations: LPS, lipopolysaccharide; NO, nitric oxide; Hb, hemoglobin; ESR, electron spin resonance; HNE, 4-hydroxy-2-nonenal; TBS, Tris-buffered saline; MOF, multiple-organ failure; TNF- $\alpha$, tumor necrosis factor- $\alpha$; IFN- $\gamma$, interferon- $\gamma$; SOD, superoxide dismutase; AST, aspartate aminotransferase; ALT, alanine aminotransferase; $\mathrm{NO}_{x}$, $\mathrm{NO}_{2}{ }^{-}+\mathrm{NO}_{3}{ }^{-}$; GSH, reduced glutathione; GSSG, oxidized glutathione.
} 
Multiple-organ failure (MOF) associated with sepsis is a major cause of death in patients with severe infection. The cascade leading to septic MOF involves endotoxin-induced secretion of various cytokines, including tumor necrosis factor- $\alpha$ (TNF- $\alpha$ ) and others, by monocytes and formation of reactive oxygen species by polymorphonuclear leukocytes. Oxidative stress induced by these toxic substances decreased the endogenous levels of antioxidants such as vitamin $\mathrm{C}$ in patients ( 1 ) and animals with sepsis (2). Endotoxin also decreased hepatic levels of coenzyme Q10, $\alpha$-tocopherol, and reduced glutathione (GSH). Thus an imbalance between endogenous antioxidants and generated reactive oxygen species seems to occur in patients with endotoxemia $(1,3-5)$. Based on such a concept, various antioxidants have been tested as possible therapeutics for septic shock. Some, such as black tea extract (6), N-acetylcysteine (7), and L-cysteine (8), decreased tissue injury in animals with endotoxin shock and MOF. However, the therapeutic potential of Nacetylcysteine was not apparent in patients with severe sepsis (9). Endotoxininduced liver injury and increased levels of plasma transaminases in animals were only slightly suppressed by treating with either superoxide dismutase (SOD; EC 1.15.1.1), catalase (EC 1.11.1.6), $\alpha$-tocopherol, or xanthine oxidase inhibitor allopurinol (10). Furthermore, endotoxin-dependent tissue injury also occurred in transgenic mice overexpressing $\mathrm{Cu} / \mathrm{Zn}$-SOD to an extent similar to that in control animals (11). Since various intermediates of reactive oxygen species react with different target molecules, it might be important to inhibit different steps of tissue injury caused by reactive intermediates by means of a combination of various antioxidants. Although the effects of individual antioxidants on endotoxemic tissue injury have been studied extensively, the effects of a combined use of antioxidants remain to be elucidated.

Antioxidant biofactor (AOB) is a commercially available unique processed grain food that contains extracts from wheat germ, soybeans, rice bran, tear grass, sesame, wheat, citron, green tea, green leaf extract, and malted rice (12). A chemical analysis of $\mathrm{AOB}$ shows the presence of various phenolic compounds, trace elements, and vitamins with antioxidant properties, such as $\alpha$-tocopherol and vitamin $\mathrm{C}$ (Table 1). AOB has been known to scavenge superoxide and hydroxyl radicals generated by activated neutrophils and to inhibit lipid peroxidation. It also improved clastogenic factors in plasma from Chernobyl liquidators (13). Based on these properties, $\mathrm{AOB}$ inhibits tissue injury caused by reactive oxygen species both in vitro and in vivo (14). The present work describes the effect of AOB on liver injury induced by endotoxin in rats.

\section{MATERIALS AND METHODS}

Chemicals. LPS (E. coli 055:B5) was obtained from DIFCO (Detroit, MI). AOB was provided by AOA Japan (Kobe). Other reagents used were of analytical grade available from Wako Chemicals (Osaka). Mouse TNF- $\alpha$ ELISA kit was obtained from Genzyme (Cambridge, MA); the specific antibody cross-reacted 
Table 1. Chemical analysis of AOB ingredients.

\begin{tabular}{|c|c|c|}
\hline & \multicolumn{2}{|c|}{ Content (mg/100 g on a dry weight basis) } \\
\hline & $\mathrm{AOB}$ & Basal diet \\
\hline \multicolumn{3}{|l|}{ Trace element } \\
\hline Potassium & 1,400 & 870 \\
\hline Phosphorus & 760 & 830 \\
\hline Magnesium & 321 & 240 \\
\hline Iron & 10.0 & 15.4 \\
\hline Calcium & 203 & 1,110 \\
\hline Sodium & 55.5 & 240 \\
\hline Zinc & 6.6 & 5.1 \\
\hline \multicolumn{3}{|l|}{ Phenolic compounds } \\
\hline Rutin & 33.0 & - \\
\hline Genistin & 31.0 & - \\
\hline Daidzin & 24.0 & - \\
\hline Hyperin & 9.9 & - \\
\hline Isoquercitrin & 4.6 & - \\
\hline Daidzein & 3.0 & - \\
\hline Genistein & 2.4 & - \\
\hline Kaemperol & n.d. & - \\
\hline Quercetin, quercitrin & n.d. & - \\
\hline \multicolumn{3}{|l|}{ Vitamins } \\
\hline Ascorbic acid & 282 & 4 \\
\hline Tocopherols & 24.5 & 9.4 \\
\hline Retinol (IU) & n.d. & 2,117 \\
\hline Carotene & 2.3 & - \\
\hline Vitamin B6 & 0.97 & 0.82 \\
\hline Vitamin B12 & n.d. & 5.1 \\
\hline
\end{tabular}

These constituents were analyzed by Japan Food Research Laboratories and were authorized by the Japanese government. AOB was evaporated to dryness. All values were expressed as mg per $100 \mathrm{~g}$ on a dry weight basis extract of AOB; n.d., not detectable.

with rat TNF- $\alpha$ (15). Rat IFN- $\gamma$ ELISA kit was purchased from Gibco BRL (Gaithersburg, MD).

Animals. Male Wistar rats, 200-230g, were purchased from SLC (Shizuoka). Under light ether anesthesia, lipopolysaccharide (LPS, $10 \mathrm{mg} / \mathrm{kg}$ ) was intravenously injected into rats. Before the experiments, each rat was housed in a separate cage and the control group was allowed free access to a basal diet (Oriental Yeast MF, $\left.15 \mathrm{~g} \cdot \mathrm{d}^{-1}\right)$. In the AOB-treated group, an AOB-containing diet $\left(14 \mathrm{~g} \cdot \mathrm{d}^{-1}\right.$ of basal diet and $1 \mathrm{~g} \cdot \mathrm{d}^{-1}$ of $\mathrm{AOB}$ ) was given for $3 \mathrm{~d}$. The experimental design was approved by the Committee of Osaka City University for Care and Use of Laboratory Animals. Under pentobarbital anesthesia $(50 \mathrm{mg} / \mathrm{kg}$, i.p.), blood samples were obtained from the abdominal aorta by using heparin-containing syringes. Plasma 
samples were prepared by centrifugation at $3,000 \times g$ and $0^{\circ} \mathrm{C}$ for $10 \mathrm{~min}$ and were stored on ice until assay.

Analysis of plasma samples. Aspartate aminotransferase (AST; EC 2.6.1.1) and alanine aminotransferase (ALT; EC 2.6.1.2) levels in plasma were determined by a Hitachi $7450 \mathrm{E}$ autoanalyzer (Hitachi, Ibaraki). Plasma levels of TNF- $\alpha$ and IFN- $\gamma$ were measured by using ELISA kits.

Histological evaluation of hepatic injury. Excised liver tissues were fixed with $10 \%$ buffered formalin and embedded in paraffin. Sections were stained with hematoxylin and eosin.

Measurement of nitrosylhemoglobin $(\mathrm{NO}-\mathrm{Hb})$. The blood samples $(400 \mu \mathrm{L})$ were collected in tubes for electron spin resonance spectrometry (ESR), quickly frozen in liquid nitrogen, and analyzed at $110 \mathrm{~K}$ using a JES-RE1X apparatus (JEOL, Tokyo) with $100 \mathrm{kHz}$ field modulation. ESR analysis was conducted with the microwave power of $8 \mathrm{~mW}$ at a frequency of $9.108 \mathrm{GHz}, 325 \pm 250 \mathrm{mT}$ field, 1 min sweep time, $0.63 \mathrm{mT}$ modulation amplitude, and $0.03 \mathrm{~s}$ time constant. The double integrated signal for NO-hemoglobin complex (NO-Hb, $g=2)$ was compared with that for $\mathrm{CuSO}_{4}$-EDTA reference solution, previously described (16).

Analysis of NO metabolites in plasma and urine. Plasma and urine samples were deproteinized by acidification with $6 \%$ sulfosalicylic acid (SSA) followed by centrifugation at $10,000 \times g$ for $15 \mathrm{~min}$. The supernatant fractions $(100 \mu \mathrm{L})$ were mixed with $150 \mu \mathrm{L}$ of $5 \% \mathrm{NH}_{4} \mathrm{Cl}$ and $30 \mu \mathrm{L}$ of $5 \% \mathrm{NaOH}$. Nitrate in the samples was reduced by a cadmium column to $\mathrm{NO}_{2}{ }^{-}$, which reacted with Griess reagent to form a purple azo dye (17). The total amounts of $\mathrm{NO}_{2}{ }^{-}\left(\mathrm{NO}_{2}{ }^{-}+\mathrm{NO}_{3}{ }^{-}, \mathrm{NO}_{x}\right)$ were determined by high performance liquid chromatography. The reaction was developed in a $60^{\circ} \mathrm{C}$ water bath, and the absorbance at $546 \mathrm{~nm}$ was detected by a flow-through spectrophotometer.

Determination of glutathione and thiols in the liver. Total glutathione (reduced glutathione and oxidized glutathione: GSH $+2 \mathrm{GSSG}$ ) and thiol levels in the liver were determined by the methods of Tietze (18) and Ellman (19), respectively. Under urethane anesthesia ( $1 \mathrm{~g} / \mathrm{kg}$, i.p.), the liver was perfused though the abdominal aorta with $50 \mathrm{~mL}$ of ice-cold saline. The excised liver was immediately homogenized in 3 volumes of ice-cold 5\% SSA. After centrifugation at $12,000 \times g$ for $15 \mathrm{~min}$, concentrations of thiols and total glutathione in the acid-soluble fractions were determined.

Measurement of glutathione reductase and glutathione peroxidase. Fresh liver $(200 \mathrm{mg}$ ) was homogenized in $1.5 \mathrm{~mL}$ of ice-cold $0.01 \mathrm{M}$ potassium phosphate buffer, $\mathrm{pH} 7.4$, containing $30 \mathrm{~mm} \mathrm{KCl}$. The supernatant was obtained after centrifugation of the homogenate at $16,000 \times g$ at $0^{\circ} \mathrm{C}$ for $30 \mathrm{~min}$. Glutathione reductase (EC 1.6.4.2) and glutathione peroxidase (EC 1.11.1.9) activities were determined by the methods of Bergmeyer (20) and Günzler et al (21), respectively.

Western blot analysis. 4-Hydroxy-2-nonenal (HNE) and its protein adducts have been demonstrated to be good markers for lipid peroxidation induced by reactive oxygen species (22). For the estimation of HNE-modified proteins in the 
liver, the homogenates from control and LPS-treated rats were incubated in Laemmli sample buffer for $3-5 \mathrm{~min}$ at $100^{\circ} \mathrm{C}(23)$. The incubated samples $(10 \mu \mathrm{g}$ protein) were subjected to polyacrylamide gel electrophoresis (PAGE) in SDS. The gel was transblotted to Immobilon PVDF membrane. The membrane was incubated with $2 \%$ BSA in Tris-buffered saline containing 10\% Tween 20 (TBS/Tween) for blocking, washed with TBS/Tween, then treated with the monoclonal antibody (HNEJ-2) specific for HNE-histidine adduct (24). This procedure was followed by reacting with horseradish peroxidase-conjugated rabbit antimouse IgG (diluted 1:2,000). Chemiluminescent enhancers (Amersham, Buckinghamshire, England) were used for visualization by autoradiography. The mean density of the band area was measured by using NIH Image (version 1.56) after obtaining a black-and-white image as PICT files by an image scanner.

Generation of $\mathrm{NO}, \mathrm{O}_{2}{ }^{-}$and lipid peroxidation in $\mathrm{J} 774.2$ cells. The murine macrophage cell line J 774.2 was purchased from JCRB cell bank (Osaka) and maintained in DMEM culture medium (Gibco, BRL, Gaithersburg, MD) supplemented with $10 \%$ fetal calf serum, $2 \mathrm{~mm}$ L-glutamine, $100 \mathrm{U} / \mathrm{mL}$ penicillin, $100 \mu \mathrm{g} / \mathrm{mL}$ streptomycin, and $20 \mathrm{~mm}$ glucose. Cells were cultured for $48 \mathrm{~h}$ at $37^{\circ} \mathrm{C}$ in an atmosphere of $5 \% \mathrm{CO}_{2}$ in 12 -well Costar plates at $2 \times 10^{6}$ cells per $2 \mathrm{~mL}$ of DMEM. To each well was added $2 \mathrm{~mL}$ of control medium (control) or medium containing $10 \mu \mathrm{g} / \mathrm{mL}$ LPS in the presence or absence of various concentrations of AOB. Superoxide generation was determined $6 \mathrm{~h}$ after LPS treatment. Concentration of $\mathrm{NO}_{2}{ }^{-}$in the medium was determined $6 \mathrm{~h}$ after LPS treatment. Superoxide was determined by the cytochrome $c$ reduction method (25). Generation of lipid peroxidation in J 774.2 cells was determined $6 \mathrm{~h}$ after LPS treatment. The collected cells were lysed by repeating the freeze/thaw procedure 3 times in distilled water. Lipid peroxidation in the cells was measured by using a colorimetric assay kit (BIOXYTECH LPO-586, OXIS International, Portland, OR) and expressed as a sum of as malonaldehyde and 4-hydroxyalkenals.

Statistical analysis. All values in the figures are expressed as means $\pm \mathrm{SE}$ and analyzed by using 2-way ANOVA followed by the Fischer $t$-test. The difference between $\mathrm{AOB}$ and control groups was considered significant at $p<0.05$.

\section{RESULTS}

\section{Survival and hepatic injuries of LPS-treated rats}

Figure 1 shows the survival rate of LPS-treated rats. Fifty percent of LPStreated rats died within $24 \mathrm{~h}$ of treatment. The administration of AOB significantly decreased the mortality of rats. To evaluate hepatic injury, plasma AST and ALT levels were measured. These levels markedly increased in LPS-treated rats by some mechanism inhibited by AOB (Fig. 2).

Figure 3 shows that AOB inhibits the progression of LPS-induced damage. Microscopic examination of the liver from LPS-treated rats revealed the presence of focal necrosis and infiltration of neutrophils (control). On the other hand, such 


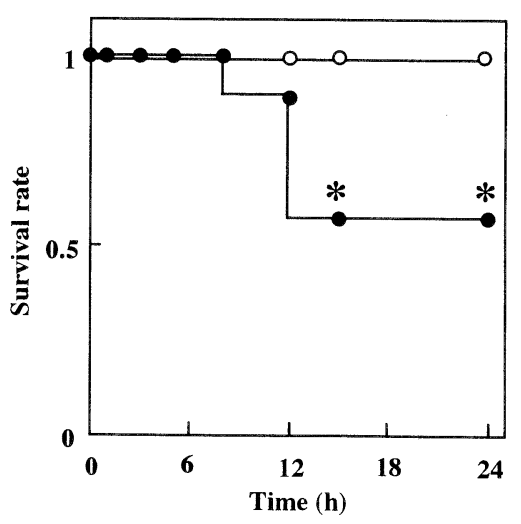

Fig. 1. Effect of AOB on the survival rate of LPS-treated rats. AOB was orally given for $3 \mathrm{~d}(1 \mathrm{~g} / \mathrm{d})$ with basal diet before the experiments. LPS $(10 \mathrm{mg} / \mathrm{kg})$ was intravenously administered into rats, of which the survival rate was observed over $24 \mathrm{~h}$. Ten rats were used for each group. Closed circle, LPS-treated group; open circle, AOB-treated group (LPS treatment in AOB-prefed rats). ${ }^{*}$ Significantly different at $p<0.05$ from LPS-treated group.
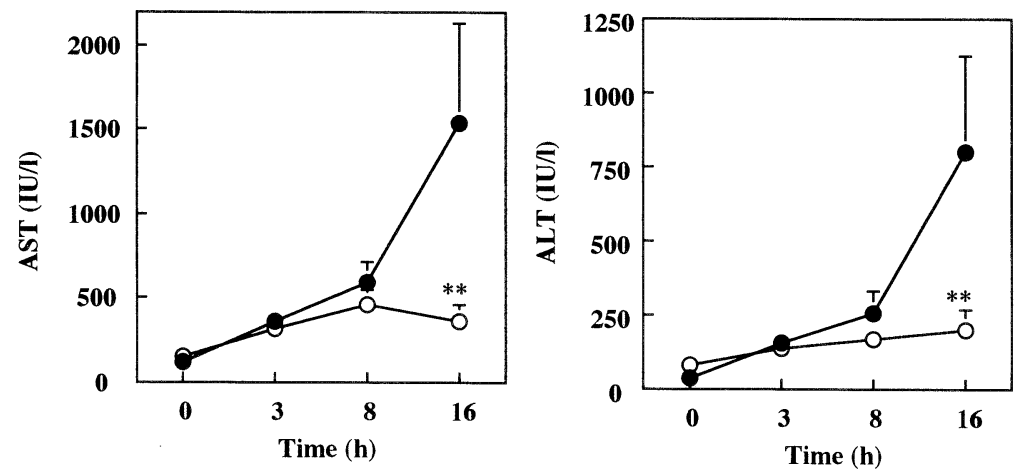

Fig. 2. Effect of AOB on plasma activities of aspartate aminotransferase (AST) and alanine aminotransferase (ALT). LPS and AOB were administered as described in Fig. 1. Under light ether anesthesia, plasma samples were collected via the abdominal aorta. Values are means \pm SE $(n=5-10)$. Closed circle, LPS-treated group; open circle, AOB-treated group. ${ }^{* *} p<0.01$ as compared with LPS-treated group.

pathological findings were not observed in livers from AOB-treated rats.

NO metabolites and cytokines in plasma

Kinetic analysis by ESR revealed that NO-Hb levels in blood markedly increased and reached a maximum $8 \mathrm{~h}$ after LPS injection (Fig. 4). Plasma and urinary levels of $\mathrm{NO}_{x}\left(\mathrm{NO}_{2}{ }^{-}+\mathrm{NO}_{3}{ }^{-}\right)$also increased after LPS treatment. The administration of AOB did not affect the blood levels of $\mathrm{NO}-\mathrm{Hb}$ and $\mathrm{NO}_{x}$. 
Normal

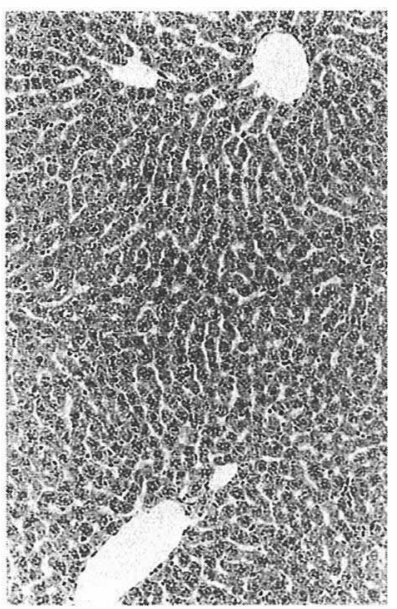

Control

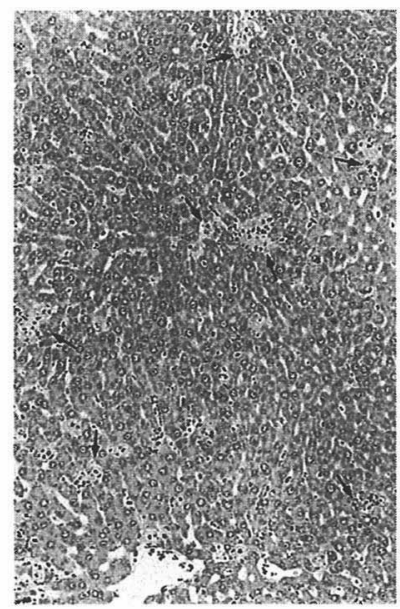

$+\mathrm{AOB}$

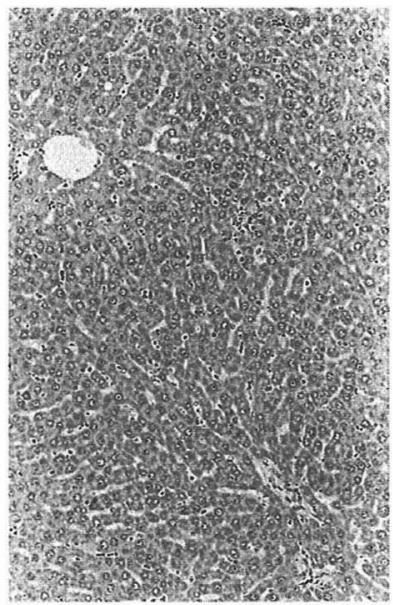

Fig. 3. Histology of liver specimens from normal, LPS-treated (Control), and LPS + AOB-prefed rats. The liver from LPS-treated rats shows necrosis of hepatocytes and infiltration of neutrophils (arrows). The liver from the AOB-treated group shows no abnormal finding. Magnification: $\times 100$.
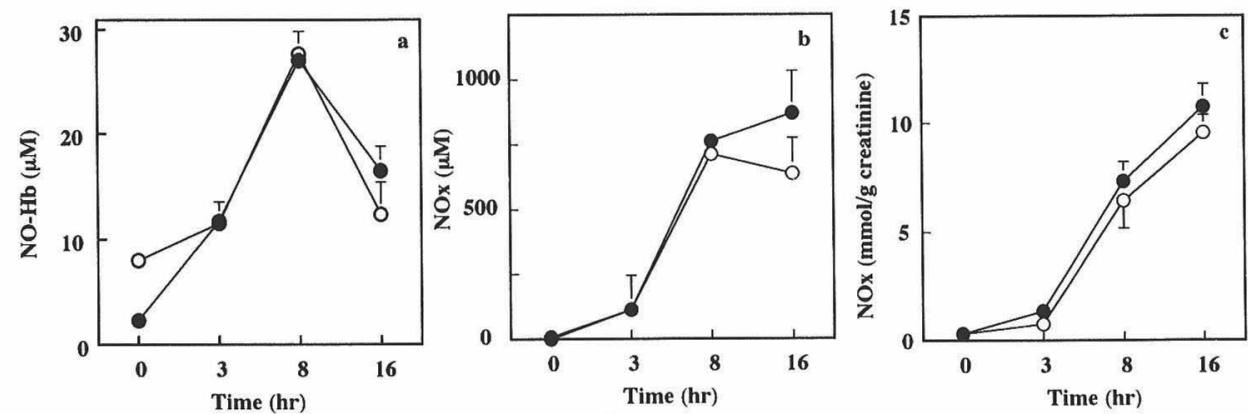

Fig. 4. Plasma levels of NO metabolites in LPS-treated rats. LPS and AOB were administered as described in Fig. 1. Levels of urinary $\mathrm{NO}_{x}$ were corrected by creatinine levels. Values are means $\pm \operatorname{SE}(n=5-10)$. a, NO-Hb in blood; b, nitrite + nitrate $\left(\mathrm{NO}_{x}\right)$ in plasma; c, urinary $\mathrm{NO}_{x}$. Closed circle, LPS-treated group; open circle, AOB-treated group.

As shown in Table 2, the plasma levels of TNF- $\alpha$ and IFN- $\gamma$ markedly increased after LPS treatment, and AOB failed to inhibit the increase.

\section{Hepatic glutathione status}

The hepatic levels of free thiols and glutathione decreased $8 \mathrm{~h}$ after LPS administration (Fig. 5). Although $\mathrm{AOB}$ itself had no appreciable effect on the 
Table 2. Effect of $\mathrm{AOB}$ on cytokine production levels in plasma.

\begin{tabular}{clcccc}
\hline & & \multicolumn{5}{c}{ Time $(\mathrm{h})$} \\
\cline { 3 - 6 } & & 0 & 1.5 & 3 & 8 \\
\hline $\mathrm{TNF}-\alpha$ & Control & $0.08 \pm 0.01$ & $6.39 \pm 0.06$ & $0.58 \pm 0.03$ & n.d. \\
$(\mathrm{ng} / \mathrm{mL})$ & AOB & $0.09 \pm 0.02$ & $6.45 \pm 0.08$ & $0.40 \pm 0.01$ & n.d. \\
$\mathrm{INF}-\gamma$ & Control & $0.05 \pm 0.01$ & n.d. & $56.9 \pm 6.1$ & $20.7 \pm 2.6$ \\
$(\mathrm{ng} / \mathrm{mL})$ & AOB & $0.08 \pm 0.01$ & n.d. & $49.1 \pm 5.5$ & $16.9 \pm 3.5$ \\
\hline
\end{tabular}

At the indicated times after LPS administration $(10 \mathrm{mg} / \mathrm{kg})$, plasma TNF- $\alpha$ and IFN- $\gamma$ were determined as described in the text. Values are means \pm SE $(n=4-5)$. n.d., not determined.

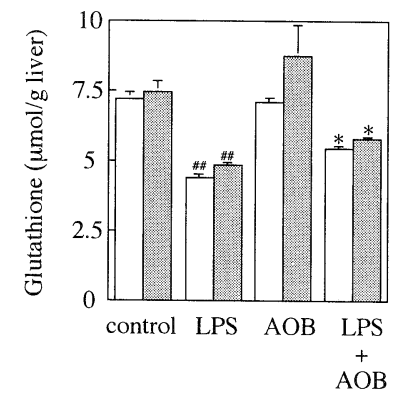

Fig. 5. Effect of AOB on hepatic glutathione levels of LPS-treated rats. Glutathione and free $\mathrm{SH}$ levels in the liver were determined with control and AOB-treated rats $8 \mathrm{~h}$ after intravenous injection of $10 \mathrm{mg} / \mathrm{kg}$ of LPS. Data show means $\pm \operatorname{SE}(n=5)$. $\square$, free thiols; $\square$, glutathione. ${ }^{\#} p<0.01$ as compared with normal. ${ }^{*} p<0.05$ as compared with LPS-treated group.

concentrations of glutathione and free thiols in the liver of normal rats, it inhibited the LPS-induced decrease of hepatic thiols. Under the same conditions, LPS increased glutathione reductase activity in the liver (Fig. 6). AOB did not affect the LPS-induced change in hepatic glutathione reductase activity. LPS also increased hepatic activity of glutathione peroxidase $3 \mathrm{~h}$ after administration. The elevated activity returned to the initial level $3 \mathrm{~h}$ after LPS treatment. The increased activity of glutathione peroxidase remained high in the AOB-treated group even $8 \mathrm{~h}$ after LPS treatment.

\section{LPS-induced changes in HNE-modified proteins}

Figure 7 shows the effect of AOB on the LPS-induced changes in hepatic levels of HNE-modified proteins. Kinetic analysis using anti-HNE antibody revealed that several proteins were modified by HNE. Among various proteins, $29 \mathrm{kDa}$ protein was most sensitive to modification by HNE. As a result of densitometry, the amount 

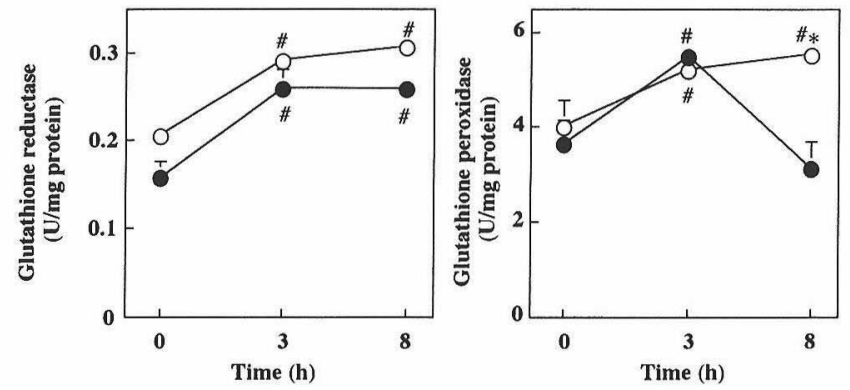

Fig. 6. Effect of $\mathrm{AOB}$ on glutathione reductase and glutathione peroxidase in the liver. LPS and AOB were administered to rats as described in Fig. 1. Hepatic glutathione reductase and glutathione peroxidase were measured at 0,3 , and $8 \mathrm{~h}$ after LPS treatment. Data show means $\pm \mathrm{SE}(n=5)$. Closed circle, LPS-treated group; open circle, AOB-treated group. ${ }^{\sharp} p<0.05$ as compared with normal group. ${ }^{*} p<0.05$ as compared with LPS-treated group.

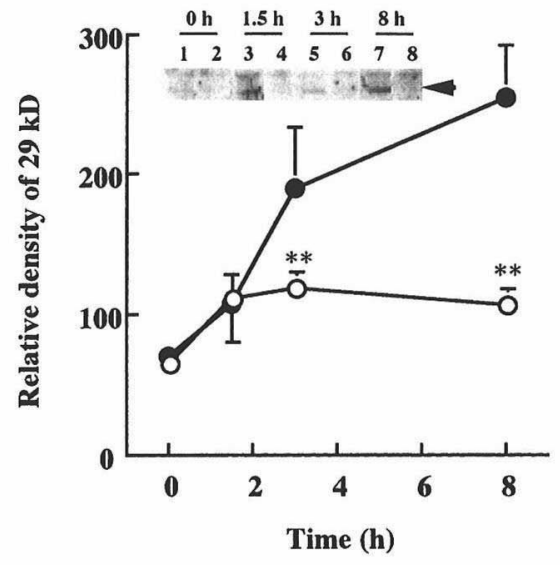

Fig. 7. Effect of AOB on hepatic levels of HNE-modified proteins. At the indicated times, rats were treated with LPS $(10 \mathrm{mg} / \mathrm{kg})$. AOB was administered as described in Fig. 1. HNE-modified proteins in liver cytosol were analyzed by using anti-HNE antibody. Densitometric analysis of HNE-modified proteins $(29 \mathrm{kDa})$ was performed. Inserted figure shows Western blots of HNE-modified proteins. Lanes $1,3,5,7$, and 2, 4, 6, 8, show samples from control and AOB-treated groups, respectively. Data show means $\pm \mathrm{SE}(n=5)$. Closed circle, LPS-treated group; open circle, AOB-treated group. ${ }^{* *} p<0.01$ as compared with LPS-treated group.

of HNE-modified $29 \mathrm{kDa}$ protein proved to increase 3- and 4-fold 3 and $8 \mathrm{~h}$ after LPS treatment, respectively. AOB depressed the formation of these proteins.

Generation of $\mathrm{O}_{2}{ }^{-}, \mathrm{NO}$, and lipid peroxidation in $\mathrm{J} 774.2$ cells

LPS treatment generated both superoxide and $\mathrm{NO}_{2}{ }^{-}$in $\mathrm{J} 774.2$ cells. Figure 8 and Table 3 show the effect of AOB on the LPS-induced generation of superoxide 


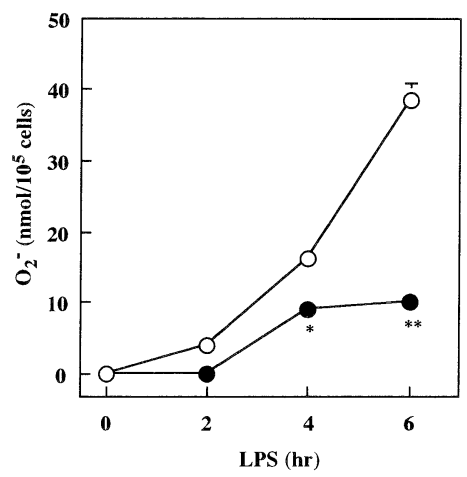

Fig. 8. Effect of LPS on the superoxide generation by J 774.2 cells. After incubation of $10^{5}$ cells with $10 \mu \mathrm{g} / \mathrm{mL}$ of LPS and $0.05 \mathrm{mg} / \mathrm{mL}$ of $\mathrm{AOB}$, superoxide generation in the medium was determined. Concentrations of $\mathrm{O}_{2}{ }^{-}$in the medium were determined at $6 \mathrm{~h}$ after LPS treatment. Data show means \pm SE $(n=4) .{ }^{*} p<0.05$, ${ }^{* *} p<0.01$, as compared with LPS-treated rats. Closed circle, LPS-treated group; open circle, AOB-treated group.

Table 3. Effect of $\mathrm{AOB}$ on the generation of $\mathrm{O}_{2}{ }^{-}$and $\mathrm{NO}_{2}{ }^{-}$after LPS treatment by J 774.2 cells.

\begin{tabular}{ccc}
\hline $\begin{array}{c}\mathrm{AOB} \\
(\mathrm{mg} / \mathrm{mL})\end{array}$ & $\begin{array}{c}\mathrm{O}_{2}{ }^{-} \\
\left(\mathrm{nmol} / \mathrm{h} / 10^{5} \text { cells }\right)\end{array}$ & $\begin{array}{c}\mathrm{NO}_{2}{ }^{-} \\
\left(\mathrm{nmol} / 6 \mathrm{~h} / 10^{5} \text { cells }\right)\end{array}$ \\
\hline 0 & $7.94 \pm 0.89$ & $5.13 \pm 0.85$ \\
0.03 & $3.87 \pm 0.56^{*}$ & $4.73 \pm 0.86$ \\
0.1 & 0 & $4.81 \pm 0.54$ \\
1.0 & 0 & $4.56 \pm 0.68$ \\
10.0 & 0 & $3.78 \pm 1.03$ \\
\hline
\end{tabular}

After the incubation of $10^{5}$ cells with $10 \mu \mathrm{g} / \mathrm{mL}$ of LPS and varying concentrations of AOB, the generation of $\mathrm{O}_{2}{ }^{-}$and the levels of $\mathrm{NO}_{2}{ }^{-}$in the medium were determined. Concentrations of $\mathrm{O}_{2}{ }^{-}$in the medium were determined for $1 \mathrm{~h}$ between $5-6 \mathrm{~h}$ after LPS treatment. Concentrations of $\mathrm{NO}_{2}{ }^{-}$in the medium were determined at $6 \mathrm{~h}$ after LPS treatment. Data show mean \pm SE. ${ }^{*} p<0.05$ as compared with LPS-treated.

and $\mathrm{NO}_{2}{ }^{-}$in $\mathrm{J} 774.2$ cells. LPS increased the cellular production of both superoxide and $\mathrm{NO}_{2}{ }^{-}$. Table 4 shows the effect of AOB on lipid peroxidation $6 \mathrm{~h}$ after LPS treatment. AOB strongly inhibited the generation of superoxide and lipid peroxidation, but not of $\mathrm{NO}_{2}{ }^{-}$.

\section{DISCUSSION}

Free radicals have been postulated to underlie the mechanism of liver injury 
Table 4. Effect of AOB on LPS-induced lipid peroxidation by $\mathrm{J} 774.2$ cells.

\begin{tabular}{ccc}
\hline \multirow{2}{*}{$\begin{array}{c}\mathrm{AOB} \\
(\mathrm{mg} / \mathrm{mL})\end{array}$} & \multicolumn{2}{c}{ After LPS administration $(\mathrm{h})$} \\
\cline { 2 - 3 } & 0 & 6 \\
\hline 0 & $24.5 \pm 1.70$ & $46.2 \pm 8.28$ \\
0.05 & $25.1 \pm 3.05$ & $30.3 \pm 2.66^{*}$ \\
0.1 & $25.2 \pm 3.98$ & $27.7 \pm 4.11^{*}$ \\
\hline
\end{tabular}

After incubation of $10^{5}$ cells with $10 \mu \mathrm{g} / \mathrm{mL}$ of LPS and varying concentrations of AOB, levels of lipid peroxidation in the cells were determined at $6 \mathrm{~h}$ after LPS treatment. Data show mean \pm SE. ${ }^{*} p<0.05$ as compared with control $(6 \mathrm{~h})$.

in endotoxemic subjects. The present work clearly demonstrates that AOB markedly inhibited liver injury and increased the survival rate of LPS-treated endotoxemic rats.

Although AOB inhibited liver injury by LPS, it failed to suppress the enhanced generation of NO, NO-Hb, and toxic cytokines. Since xanthine oxidase (EC 1.1.3.22) is markedly activated in the liver of endotoxemic rats, this enzyme has been postulated to be involved in the generation of toxic metabolites. However, alloprinol, a potent inhibitor of the enzyme, increased the survival rate of LPS-treated rats only slightly (10). Thus the enzyme may not play an important role in the pathogenesis of liver injury in endotoxemic rats. Oxygen radicals are derived from activated macrophages and neutrophils. AOB scavenged the superoxide radical without affecting its generation by xanthine oxidase (12) and activated neutrophils (14). The present work also demonstrates that AOB scavenges the superoxide radical generated by LPS-stimulated J 774.2 without affecting the cellular production of NO. Since superoxide rapidly reacts with $\mathrm{NO}\left(\mathrm{K}=6.7 \times 10^{9} \mathrm{M}^{-1} \mathrm{~s}^{-1}\right)$, it is likely that $\mathrm{AOB}$ inhibits the generation of toxic peroxinitrite in LPS-treated rats.

AOB also inhibited the LPS-induced decrease in GSH levels in the liver. Because glutathione reductase and peroxidase after LPS administration remained high in the AOB-treated group, AOB may have enhanced the regeneration of GSSG and the GSH-dependent degradation of lipid hydroperoxides. Consistent with this notion, the present finding showed that $\mathrm{AOB}$ also suppressed the formation of HNE-protein adducts in the liver and lipid peroxidation in $\mathrm{J} 774.2$ cells. Reactive oxygen species initiate free radical chain reaction and induce lipid peroxidation. This chain reaction generates various aldehydes, including HNE. Although LPS enhanced the formation of HNE-protein adducts with different molecular weights, this modification was characteristic of $29 \mathrm{kDa}$ protein(s). AOB strongly decreased the formation of HNE-modified proteins, including $29 \mathrm{kDa}$ protein. The biochemical properties of $29 \mathrm{kDa}$ protein(s) remain to be further studied.

$\mathrm{N}$-Acetylcysteine has been successfully used as an antioxidant therapeutic. However, the intravenous administration of $\mathrm{N}$-acetylcysteine $(3 \mathrm{~g} / \mathrm{d})$ had no ap- 
preciable effects either on the plasma levels of glutathione and lipid peroxides or on the prognosis of patients with endotoxemia (26). Because different species of reactive oxygen metabolites react with different molecules and appear at different steps of inflammation, the administration of a single type of antioxidant may not be sufficient for the treatment of patients with severe endotoxemia. And because AOB contains various types of antioxidants with both hydrophobic and hydrophilic natures that scavenge different types of free radicals in different cellular compartments and inhibit lipid peroxidation, these components may synergistically function in decreasing oxidative stress elicited in patients with endotoxemia. Thus AOB may have a therapeutic potential to inhibit liver injury and to increase the survival rate of patients with severe endotoxemia.

We gratefully thank Dr. M. Nishikawa for technical assistance in regard to cell culture.

\section{REFERENCES}

1) Galley FH, Davies JM, Webster RN. 1996. Ascorbyl radical formation in patients with sepsis: effect of ascorbate loading. Free Rad Biol Med 20: 139-143.

2) Rojas C, Cadenas S, Herrero A, Mendez J, Barja G. 1996. Endotoxin depletes ascorbate in the guinea pig heart. Protective effects of vitamins $\mathrm{C}$ and $\mathrm{E}$ against oxidative stress. Life Sci 8: 649-657.

3) Downing C, Piripitsi A, Bodenham A, Schorah CJ. 1993. Plasma vitamin C in critically ill patients. Proc Nut Soc 52: 314A (abstract).

4) Goode HF, Cowley HC, Walker BE, Howdle PD, Webster NR. 1995. Decreased antioxidant status and increased lipid peroxidation in patients with septic shock and secondary organ dysfunction. Crit Care Med 23: 646-651.

5) Richard M, Lemonnier M, Thibault M, Couturier P, Auzepy P. 1990. Vitamine E deficiency and lipoperoxidation during adult respiratory distress syndrome. Crit Care Med 18: 4-9.

6) Amarakoon AM, Tappia PS, Grimble RF. 1995. Endotoxin induced production of interleukin- 6 is enhanced by vitamin $\mathrm{E}$ deficiency and reduced by black tea extract. Inflamm Res 7: 301-305.

7) Bakker J, Zhang H, Depierreux M, van-Asbeck S, Vincent JL. 1994. Effects of $\mathrm{N}$-acetylcysteine in endotoxic shock. J Crit Care 2: 36-43.

8) Falsini S, Cellai MP, Angiolini P, Cavuta M, Novelli GP. 1994. Reduced glutathione and L-cysteine in endotoxic shock in the rat. Minerva Anestesiol 9: 413-418.

9) Henderson A, Hayes P. 1994. Acetylcysteine as a cytoprotective antioxidant in patients with severe sepsis: potential new use for an old drug. Ann Pharmacother 9: 1086-1088.

10) Shibayama Y, Nakata K. 1993. Effect of exogenous antioxidant enzymes and antioxidants on the development of endotoxin-induced hepatocellular necrosis in rats. Exp Toxicol Pathol 5: 337-340.

11) De Vos S, Epstein CJ, Cho SK, Koeffler HP. 1995. Transgenic mice overexpressing human copper/zinc-superoxide dismutase $(\mathrm{Cu} / \mathrm{Zn} \mathrm{SOD})$ are not resistant to endotoxic shock. Biochem Biophys Res Commum 208: 523-531.

12) Minamiyama $Y$, Yoshikawa $T$, Tanigawa $T$, Takahashi $S$, Naito $Y$, Ichikawa $H$, Kondo M. 1994. Antioxidative effects of processed grain food. J Nutr Sci Vitaminol 40: 467477. 
13) Emerit I, Oganesian N, Artyunian R, Pogossian A, Sarkisian T, Cernjavski L, Levy A, Feingold J. 1997. Oxidative stress-related clastogenic factors in plasma from Chernobyl liquidators: protective effects of antioxidant plant phenols, vitamins and oligoelements. Mutat Res 377: 239-246.

14) Minamiyama Y, Sato E, Takemura S, Inoue M, Yoshikawa T. 1997. Oxidative stress and antioxidant biofactor (AOB). In: Food and Free Radicals (Hiramatsu M, Yoshikawa T, Inoue M, eds), p 137-140. Plenum Press, New York.

15) Witthaut R, Farhood A, Smith CW, Jaeschke A. 1994. Complement and tumor necrosis factor-alpha contribute to Mac-1 (CD11b/CD18) up-regulation and systemic neutrophil activation during endotoxemia in vivo. J Leukoc Biol 55: 105-111.

16) Kosaka H, Sawai Y, Sakaguchi H, Kumura E, Harada N, Watanabe M, Shiga T. 1994. ESR spectral transition by arteriovenous cycle in nitric oxide hemoglobin of cytokine-treated rats. Am J Physiol 266: C1400-C1405.

17) Green CL, Wagner AD, Glogowski J, Skipper LP, Wishnok SJ, Tannenbaum RS. 1982. Analysis of nitrate, nitrite and $\left[{ }^{15} \mathrm{~N}\right]$ nitrate in biological fluids. Anal Biochem 126: $131-138$.

18) Tietze F. 1969. Enzymic method for quantitative determination of nanogram amounts of total and oxidized glutathione: applications to mammalian blood and other tissues. Anal Biochem 27: 502-522.

19) Ellman GL. 1959. Tissue sulfhydryl groups. Arch Biochem Biophys 82: 70-77.

20) Bergmeyer JU. 1974. Methods of Enzymatic Analysis, p 465-466. Academic Press, New York.

21) Günzler WA, Kremers H, Flohe L. 1974. An improved coupled test procedure for glutathione peroxidase (EC 1-11-1-9) in blood. Z Klin Chem Klin Biochem 12: $444-448$.

22) Esterbauer H, Schaur RJ, Zollner H. 1991. Chemistry and biochemistry of 4-hydroxynonenal, malonaldehyde and related aldehydes. Free Radic Biol Med 11: 81-128.

23) Laemmli UK. 1970. Cleavage of structural proteins during the assembly of the head of bacteriophage T4. Nature 227: 204-210.

24) Toyokuni S, Miyake N, Hiai H, Hagiwara M, Kawakishi S, Osawa T, Uchida K. 1995. The monoclonal antibody specific for the 4-hydroxy-2-nonenal histidine adduct. FEBS Lett 359: 189-191.

25) McCord JM, Fridovich I. 1969. Superoxide dismutase. An enzymic function for erythrocuprein (hemocuprein). $J$ Biol Chem 244: 6049-6055.

26) Konrad F, Schoenberg MH, Wiedmann H, Kilian J, Georgieff M. 1995. The application of $n$-acetylcysteine as an antioxidant and mucolytic in mechanical ventilation in intensive care patients. A prospective, randomized, placebo-controlled, double-blind study. Anaesthesist 9: 651-658. 